WORKING PAPER 非 277

INDUSTRIAT RETATIONS SECTION

PRINCETON UNIVERSITY

November 1990

\title{
WAGE BARGAINING WITH ENDOGENOUS PROFITS, OVERTIME WORKING AND HETEROGENEOUS LABOR*
}

\author{
Karen Mumford and Steve Dowrick \\ Princeton University, Warwick University \\ November 1990
}

*The authors are grateful for helpful comments and advice from fellow staff, students and visitors of the Research School of Social Sciences, Australian National University, and the Industrial Relations Section, Princeton University. With special thanks to Gordon Anderson, Trevor Breusch, Bob Gregory, George Neumann, and Peter Smith for reading and commenting on early drafts. Responsibility for any mistakes or omissions is, however, entirely their own. 
Abstract

JEL \# 821

This paper estimates the role of insider power in wage determination in a unionized industry, examining the direction and magnitude of biases which may arise through failure to control for variation in both hours of work and the composition of the labor force and through failure to control for the endogeneity of measured profits. Furthermore, by examining the extent to which rent-sharing is related to exogenous demand shocks rather than to potentially endogenous productivity, we provide a test of the bargaining and 'pure' efficiency wage models, finding that the majority of the insider weighting can be explained by the bargaining model. Our data set covers earnings and profitability in the New South Wales coal industry from 1952 to 1987 . We estimate a partial adjustment model and test for co-integration of the time series in order to establish whether or not a long-run stable equilibrium exists.

Karen Mumford

Steve Dowrick

Princeton University

Warwick University 


\section{Introduction}

A number of attempts have been made in recent years to determine whether theoretical models of bargaining can help to explain wage determination. To the extent that the answer to this question is affirmative, empirical research has tried to estimate the magnitude of the bargaining or rent-sharing parameter. We argue here that tests of the bargaining hypothesis and parameter estimates may be biased if we do not control for variations in hours of work, heterogeneity of labor and the endogeneity of profits. We then proceed to estimate a bargaining model for a unionized industry, taking account of potential biases and examining the impact of various alternative specifications.

The notion that wages may be influenced by bargaining or rent-sharing between firms and employees has been formally analyzed in recent models of union bargaining and "insider-outsider" wage determination. A common thread running through both of these lines in the literature is a prediction that exogenous changes in the underlying profitability of an employer should be positively correlated with changes in wages. This prediction stands in contrast to the standard competitive model which suggests that firm characteristics which neither enter into the workers' utility functions nor affect their opportunity costs should have no impact on wages.

Another line of argument, the efficiency wage hypothesis, suggests that the causal link between firm performance and wages might run in the reverse direction. Higher wages may induce higher profitability through encouragement of either higher levels of effort, lower turnover and training costs, lower supervision costs or self-selection of higher unobservable skills. Alan Krueger 
and Lawrence Summers (1988) suggest that theories of bargaining or rent-sharing should be classified as a sub-set of efficiency wage theory, rather than as a competing theory, because a firm will only share rents if to do so is expected to be more profitable than facing threats of non-cooperation or strikes. They find extensive evidence from analysis of cross-section and panel data which indicates that inter-industry differentials in hourly earnings are substantial, and stable over time and over occupational groups, even when adjustments are made for the quality of labor and working conditions. Their interpretation of this evidence as support of a generalized efficiency wage hypothesis should probably be regarded as suggestive rather than positive since it relies on the failure of other.models to explain wage differentials rather than on explicitly testable, and falsifiable, predictions.

'Insider power' models do provide directly testable predictions linking profitability and wages. There are, moreover, important distinctions which can be tested in relation to the direction of causality. In particular, bargaining models predict that exogenous demand shocks to profitability should be passed on to wages, whereas the 'pure' efficiency wage models of effort or shirking predict no such effect.

A substantial body of recent empirical research, carried out primarily in the USA and the UK, has found positive correlations between earnings and profitability. Svejnar (1986), for example, examined time series on wages for twelve major unionized companies in the USA and estimated rent-sharing parameters which varied between six and eighty five percent and averaged around 40 percent. Karier (1985) was primarily interested in the effects of unions on profits, but a pertinent 
result from his study of a cross-section of US industries in 1972 was "that unions capture a sizable fraction of monopoly profits in concentrated industries and have little effect on profits when markets are more competitive" ( $p .41$ ). This finding implies that wages are a function of monopoly rents, a conclusion which is confirmed explicitly by Lawrence Mishel (1986) who studies a large sample of US manufacturing establishments and finds that union wage premia depend on the existence of non-competitive market structure.

Recent empirical work on insider power in UK wage determination is well summarized by David Blanchflower, Andrew Oswald and Mario Garrett (1990) who report widespread evidence that wages are influenced by 'insider variables' such as firm profitability. Their own cross-sectional study covers over one thousand establishments and leads them to the conclusion that while financial performance, product market competition and unionization are unimportant for pay determination for unskilled workers, these insider variables are significant for skilled workers; they also report that 'outsider' pressures such as external wage rates and unemployment are significant for all groups of workers. Stephen Nickell and Sushil Wadhwani (1990) estimate wage equations using cross-section and time series data on 219 UK manufacturing companies and find that insider variables, capturing a firm's ability to pay, are strongly significant. Their model predicts that bargained wages are determined by a convex combination of inside and outside factors and they estimate that the insider weighting lies between eleven and seventeen percent.

This body of empirical work does strongly suggest that non-competitive bargaining or rent-sharing can be an important aspect of wage determination. We argue, 
however, that such results should be interpreted with caution in the light of a number of methodological problems. First, it is possible that observed correlations between 'ability to pay' and wages may result from shifts along an upward-sloping labor supply schedule rather than from non-competitive rent-sharing. Second, observed profitability is an endogenous variable, affected directly by wage outcomes and perhaps indirectly through efficienc $y$ wage effects, so single equation estimates of the relationship between wages and financial performance may be subject to simultaneous equation bias. Third, particular caie must be taken to ensure that mis-measurement of the opportunity cost of labor does not yield spurious estimates of the magnitude of rents accruing to labor.

The possibility that correlation between profitability and earnings results from upward-sloping labor supply rather than from rent-sharing is particularly pertinent where hours of work are not measured. The studies cited above by Svejnar (1986), Nickell and Wadhwani (1990) and Blanchflower et al (1990), for instance, all use weekly or annual data on earnings and financial performance. Hours of work may, however, vary substantially both across industries and over time and overtime working is usually paid at a higher rate than ordinary time. To the extent that increases in profitability are associated with increases in demand for labor hours, and that is in turn met by increases in overtime working, we may expect to observe a positive correlation between profitability and weekly earnings which is perfectly consistent with competitive wage determination. In other words, estimates of the rent-sharing parameter may be biased upwards by the use of data which masks variation in hours of work ${ }^{1}$.

\footnotetext{
${ }^{1} \mathrm{Blanchflower}$ et al (1990) report that hourly wage equations yield the same results as their weekly wage equations, but this need not be the case for other data sets.
} 
Studies which use measures of observed profitability as predictors of earnings are also liable to estimation bias because unmodelled shocks to wages will, ceteris paribus, result in lower measured profitability or financial performance. Blanchflower et al (1990) argue that this will tend to bias downwards estimates of the rent-sharing parameter. It is clearly preferable to estimate the relationship either by measuring 'ability to pay' as net revenue (subtracting only non-labor costs from total revenue), as in Svejnar (1986), or by use of instrumental variables as in Nickell and Wadhwani (1990). An alternative approach is not to use the potentially endogenous measure of profitability, but to estimate a reduced form relationship with only exogenous explanatory variables. This is in essence the approach of Mishel (1986) who uses measures of an industry's competitive position to predict wage outcomes. The effectiveness of this approach depends, however, on the extent to which these exogenous measures explain 'ability to pay'. Reduced form estimation suffers from another substantial drawback in that it does not enable us to identify the magnitude of the rent-sharing parameter.

Where work intensity is not observed, the 'endogenous effort' version of the efficiency wage hypothesis is not directly testable. It is then not clear whether estimates of the rent-sharing parameter, as in svejnar (1986), are truly capturing bargaining over rents or whether they are influenced by a 'spurious correlation' whereby higher wages induce higher work effort which in turn causes higher productivity and profitability. One way of distinguishing between these two explanations is to use demand side variables as instruments to predict the exogenous component of net revenue. The efficiency wage hypothesis predicts that employers will choose an optimal wage level according to supply side, 
technological conditions; the wage will be set either at an interior solution to the profit maximization problem where the elasticity of work effort with respect to the wage is unity or at a corner solution, the reservation wage. In elther case, exogenous demand shocks to profits should have no systematic impact on the wage. So, on the one hand, evidence that demand-induced changes in profitability influence the wage can be taken to support the rent-sharing or bargaining hypotheses. On the other hand, to the extent that unrestricted estimates of the "rent-sharing" parameter are higher than estimates which are derived using demand side instruments, we can infer indirect evidence in support of the efficiency wage hypothesis.

We also note that the reliability of any estimates of the magnitude of rents accruing to labor, and their relationship with an employer's profitability, depends crucially on the accuracy with which the opportunity cost of labor can be estimated. It is important to control for heterogeneity of labor skills and of working conditions in order to ascertain whether or not workers are actually earning any non-competitive rents. These factors are likely to be particularly important in cross-sectional estimation but may also be important in time series analysis where the composition of labor skills may vary over time.

The aim of this paper is to estimate the role of insider power in wage determination in a unionized industry, examining the direction and magnitude of biases which may arise through failure to control for variation in both hours of work and the composition of the labor force and through failure to control for the endogeneity of measured profits. We also examine the extent to which rent-sharing is related to exogenous demand shocks rather than to potentially 
endogenous productivity. Our data set covers earnings and profitability in the New South Wales (NSW) coal industry from 1952 to 1987. We estimate a partial adjustment model having tested for co-integration of the time series in order to establish whether or not a long-run stable equilibrium exists.

\section{Bargaining models of rent-sharing}

We summarize here models of wage determination which involve bargaining between a union and a firm, noting that the bargaining can also be interpreted as taking place between a firm and a group of 'insiders' who are distinguished from outside labor by their firm-specific skills. We draw on the theoretical contributions of Ian McDonald and Robert Solow (1980), Andrew Oswald (1985), Jan Svejnar (1986) and Steve Dowrick (1990), but note that many variants of these models have been produced over recent years. All of these bargaining models predict a relationship between wages and the firm's profitability or 'ability to pay' which can be expressed in terms of the share of rents which accrue to labor. The aim of this section is, firstly, to clarify the interpretation of the rent-sharing parameter under various modelling assumptions. Second, we want to distinguish the relationship between wages and observed profitability, which is endogenous, from the relationship between wages and exogenous rents.

We follow standard practice in assuming a profit maximizing firm where profit, $\pi(w, L)$ is the difference between revenue net of non-labor costs (including the opportunity cost of capital), $R(L)$, and labor costs, wL, where $w$ is the wage rate and $L$ is the level of labor input. Union utility is $V(w, L)=L[u(w)-u(w)]$ where $\omega$ is the reservation wage. We assume concavity of the net revenue function and that there exists a range of values of the marginal revenue product of labor in 
excess of the reservation wage. The marginal utility of the wage to an individual worker, $u^{\prime}(w)$, is assumed positive. The concavity or convexity of the individual utility function can be interpreted in terms of risk-aversion or risk-loving in the model of expected utility under random lay-off, or it can be interpreted in terms of a cardinal utility function of a utilitarian union - see Oswald (1985). We assume that bargaining satisfies the Nash asymmetric bargaining axioms, as developed by Svejnar (1986), noting that the bargaining solution can be interpreted as the limiting case of a non-cooperative game as developed by Ken Binmore, Ariel Rubinstein and Asher Wolinsky (1986). The union's Nash bargaining parameter is $\beta$ and that of the firm is $(1-\beta)$. Note that both firm profits and union utility are defined net of each party's reservation utility or threat point.

There are two principal models of wage determination which have been used in the modern union literature. The wage bargaining or 'right to manage' model involves a two stage non-cooperative game whereby the firm chooses the level of employment to maximize profit in response to a pre-determined wage bargain. In the 'efficient bargain' model, on the other hand, the union and firm bargain simultaneously over both the wage and employment to reach an outcome on the contract curve rather than on the labor demand curve. Considerable research effort has been devoted over recent years in attempts to distinguish which of these two models is applicable to particular situations. Ben Lockwood and Alan Manning (1989) have argued that tests between the two models may have been mis-specified to the extent that they have ignored the dynamics of bargaining, whilst Martyn Andrews and Alan Harrison (1988) suggest that non-nested empirical tests are required. Our concern here is, however, not to distinguish between the 
models but to demonstrate that while both predict rent-sharing they differ in the interpretation which should be placed upon estimates of the rent-sharing coefficient.

Under the assumption of efficient bargaining we can readily derive the relationship between the wage and profits as:

$$
w \quad=\omega+\frac{\beta}{1-\beta} \mathrm{f}(\mathrm{w}) \frac{\pi(w, L)}{\mathrm{L}}
$$

where $f(w) \equiv u^{\prime}(w)(w-w) /[u(w)-u(w)]$. Note that the function $f(w)$ is the absolute elasticity of the union indifference curve with respect to the wage increment, $(w-w)$. $f(w)$ is equal to unity in the case of risk-neutrality $\left(u^{\prime \prime}(w)=0\right)$, it is less than unity in the case of risk-aversion $\left(u^{\prime \prime}(w) \leq 0\right)$ and it is greater than unity in the case of risk-loving $\left(u^{\prime \prime} ' \geq 0\right)$.

Under the assumption of wage bargaining we can define the labor demand curve $L(w)$ as the implicit solution to the profit maximization first order condition $R^{\prime}(L)=w$. We derive an expression for the wage bargaining outcome which is similar to the efficient bargain relationship (1) but involves the addition of a term representing the elasticity of labor demand with respect to the wage increment:

$$
\begin{aligned}
e(w) \equiv-(w-w) L^{\prime}(w) / L(w) . \\
w=w+\frac{\beta}{1-\beta}[f(w)-e(w)] \frac{\pi(w, L)}{L}
\end{aligned}
$$

Empirical studies which involve regression of the wage on observed profitability or financial performance are, in effect, estimating a parameter $\rho$ which equals the product of the bargaining parameter ratio, $\beta /(1-\beta)$, and a term capturing either the elasticity of the union's indifference curve, $f(w)$, in the case of efficient bargaining, or the difference between that elasticity and the 
elasticity of labor demand, $f(w)-e(w)$, in the case of wage bargaining. Linear regression analysis involves an implicit assumption that these terms are constant parameters.

Even if an assumption of constant parameters is valid, single equation estimation of $\dot{\rho}$ is likely to be biased since exogenous shocks to the wage will influence measured profits which are defined as $R(L)-w L$. We can, however, re-arrange both (1) and (2) to give an expression relating the wage to the total rent per worker, $[R(L)-\omega L] / L$.

$$
\mathrm{w}=\omega+\tau[\mathrm{R}(\mathrm{L})-\omega \mathrm{L}] / \mathrm{L}
$$

$$
\begin{aligned}
\text { where } & \tau=\beta \frac{\mathrm{f}(\mathrm{w})}{\{1-\beta+\beta \mathrm{f}(\mathrm{w})\}} & & \text { under efficient bargaining } \\
\text { or } & \tau=\beta \frac{[\mathrm{f}(\mathrm{w})-\mathrm{e}(\mathrm{w})]}{1-\beta+\beta[\mathrm{f}(\mathrm{w})-\mathrm{e}(\mathrm{w})]} & & \text { under wage bargaining. }
\end{aligned}
$$

Note that in the case of efficient bargaining with a risk-neutral union $f(w)=1$ and (3) reduces to $w=\omega+\beta[R(L)-\omega L] / L$, that is to say $\tau$ is the Nash bargaining parameter. More generally, however, single equation estimation of $\tau$ cannot distinguish between bargaining strength and the union's elasticity of substitution, $f(w)$. Nor can it distinguish between the efficient bargaining and wage bargaining models. Assuming parameter constancy we can, however, obtain from (3) an unbiased estimate of $\tau$ which we can interpret as a rent-sharing parameter. We can compare estimates of $\tau$ with the (potentially biased) estimates of $\rho$ from (1) or (2) since $\rho=\tau /(1-\tau)$.

Estimation of (3) requires that we are able to correctly measure the reservation wage, $\omega$. We expect the reservation wage for a worker with given human capital to 
be influenced by outside earnings opportunities and perhaps by some compensating differential which takes account of differences in conditions of work such as safety and environment. In our data set, however, we are only able to observe average wages outside the firm, $w^{a}$, and some limited information on the type of workers employed by the firm, that there are $L_{1}$ workers of type 1 and $L_{2}$ workers of type 2. We hypothesize that the reservation wage for each type of worker is a constant proportion of the average outside wage:

$$
\omega_{i}=\alpha_{1} w^{a} \quad i=1,2
$$

Substitution of (4) into (3), noting that the average wage $w=w_{i} L_{1} / L+w_{j} L_{j} / L$, re-arranging terms and adding an error term gives an estimating equation:

$$
w=(1-\tau) \alpha_{j} w^{a}+(1-\tau)\left(\alpha_{i}-\alpha_{j}\right) w^{a} L_{i} / L+\tau R(L) / L+\mu
$$

Using data on average outside earnings, the share of each group in total employment and net revenue per worker and making appropriate (and testable) assumptions about the structure of the error term, $\mu$, we can use (5) to identify the share parameter, $\tau$, and the reservation wage parameters, $\alpha_{1}$ and $\alpha_{2}$.

We can also test the hypothesis that the two groups of workers have different bargaining strengths or utility functions, implying that there are two different rent-sharing parameters, $\tau_{i}$ and $\tau_{j}$. If we assume that net revenue per worker is proportional to output per worker, we derive an estimating equation similar to (5) with an additional term $\left(\tau_{1}-\tau_{j}\right)\left(q_{i} R(L) / L\right)$ where $q_{i}$ is the share of output attributable to group i. Furthermore, outsider effects such as the possible effects of unemployment on the reservation wage or union bargaining strength, can be considered via variable addition tests. 


\section{Data}

Our data set considers the coal industry in the State of New South Wales (NSW), Australia, from 1952 to 1987. The main sources of this data are the Yearbooks of the NSW Joint Coal Board, the Mining Census of NSW, and the holdings of the Australian Bureau of Statistics ${ }^{2}$.

The NSW coal industry was founded in 1876 and has operated continuously. The industry has traditionally been the site of bitter battles between well organized unions and employer associations, battles which have often resulted in violent clashes, strikes, and lock outs. In response to this industrial unrest both state and Federal governments have attempted to introduce legislation constraining the parties. Up until the late 1940 s this legislation was rapidly rejected by the parties, however, with the introduction of the Coal Industry Tribunal in December 1951 the design of legislation (and government intervention) in the industry has been fairly consistent from 1952. The industry has been in the unusual position of having its own arbitrator since 1952, furthermore, it was not incorporated into a Federal award until 1990. The industry has had 1008 union membership throughout the time period. The unions and the employer associations are structured at the State level, as is the major marketing board. For these reasons we have considered the measures of unemployment and average earnings for the State of NSW, rather than for Australia as a whole.

The NSW coal industry has also undergone substantial structural change since 1952 with; a shift in production from predominantly underground to open cut

${ }^{2}$ The data set, fuller definitions of the major variables, and complete definitions of the minor variables are available from the authors. 
technology; increased market domination by the top four private producers; large gains in the relative output by state owned, or contracted, mines; and a much more influential export market.

Summary statistics for the variables used are provided in Table 1 . The average outside wage, $\mathrm{W}^{\mathrm{a}}$, represents the earnings that employees could expect to receive if they left the NSW coal industry ${ }^{3}$. There is, however, no data available on the occupations, or industries, that ex-coal industry workers are employed in and advice from relevant organizations and informants is conflicting. The average outside wage is therefore assumed to be proxied by the average full-time, nonmanagerial, earnings of males in $\mathrm{NSW}^{4}$.

The measure of net revenue, $R$, is a combined variable representing the difference between the industry's total value of output ${ }^{5}, T$, and its total costs excluding labor costs, C. Total cost is also a combined variable made up of a return to

\footnotetext{
${ }^{3}$ Some authors have used the unemployment benefit as a measure of the alternative wage, making allowance for dependents, examples are provided in Nickell and Andrews (1983) and Holly and Smith (1987). Svejnar (1986;1069) assumes that the average wages of $j$ anitors in geographic regions relative to the wages received by janitors in a specific firm, $W_{a} / W$, represents the proportionally lower wages all occupations in the firm could expect to receive outside of that firm. Hence, the alternative income, $Y_{a}$, can be expressed as $Y_{a}=Y\left(W_{a} / W\right)$, where $Y$ is the wage workers receive from the firm.

${ }^{4}$ The male wage was used, since the number of females employed in the coal industry market was negligible throughout much of the sample period.

${ }^{5}$ The selling value at the mine or quarry (or associated ore crushing or dressing plant) for the year. It is the selling value at point of sale less transport costs from the mine or quarry to the point of sale of ores, concentrates or other minerals produced during the year.
} 
capital and other non-labor costs of production ${ }^{6}$. The rate of return to capital was constructed in two parts. Firstly, the value of depreciated capital stock was established ${ }^{7}$. The opportunity cost of the capital in the NSW coal industry was then proxied by the rate of return on ten year Treasury bonds issued by the Federal Government ${ }^{8}$ multiplied by the depreciated value of capital stock.

The average industry wage, $\mathrm{W}$, is the total labor cost for the industry divided by the number of labor units, L. It represents the gross income (earnings) trat a worker in the NSW Coal Industry can expect to receive over the time period.

All variables have been deflated and are expressed in $\$ 1952$.

\section{Estimation}

Svejnar provides a static model. Results for the test of this model are recorded in column two of Table 2. At first glance, the significance and the reasonable

${ }^{6}$ Other costs of production are predominantly constructed by the sum of; the expenses of renting or leasing premises, vehicles, and plant or equipment; expenses on stores, materials, electricity, fuels, etc; and repair and maintenance expenses.

${ }^{7}$ The value of depreciated capital stock for the NSW coal industry for 1952-68 was taken from the NSW Year Books, post-1968 these depreciated values were not available and were instead estimated. Values for current expenditure on fixed assets were collected from the Mining Census for 1969-85 (and the Joint Coal Board for 1986-87). Depreciation was calculated by using the Australian National Accounts Estimates of Capital Stock where depreciation for the mining industry in totality could be estimated. Depreciation values for the coal industry alone were not available and so it was assumed that depreciation values for the coal industry could be proxied by those of the Mining Industry as a whole.

${ }^{8}$ This rate of return on capital was expressed in real terms by subtracting the percentage change in the consumer price index for the relevant period. This resulted in negative rates of return in periods of high inflation, these negative rates raise conceptual difficulties as they imply that the owners of capital actually pay the mine owners to use their capital. This difficulty was avoided by setting a minimum return of zero. 
size of the coefficients suggest support for the bargaining model. These results imply that a $\$ 1$ increase in net revenue leads to a $10.5 \mathrm{c}$ increase in the earnings of coal industry employees, that the reservation wage of underground coal miners is 1.4 times the average outside wage, and that the reservation wage of open-cut employees is substantially higher at 4.3 times the average outside wage. Closer study of the results, however, reveals severe difficulties with first-order serial correlation, heteroscedasticity and inadequate functional form; indicating that the expression is mis-specified and that little should be inferred from the estimated coefficients.

These difficulties could be due to the model not fully capturing the dynamic process taking place between the parties, indeed it may be possible that lags are relevant in the relationship being tested. For example, practical adjustment dynamics caused by the mechanisms by which firms and employees form expectations, or information delays may create a more complicated lag structure than that suggested by Svejnar's model. Also the speed of adjustment to changes in technology and skill acquisition may generate a more complex dynamic structure than that assumed in the theoretical mode $1^{9}$.

\section{Dynamic model}

Estimating a dynamic relationship within a static bargaining framework creates theoretical difficulties. As yet, it appears that economists have not been able to solve a dynamic game that results in a useful dynamic relationship for

${ }^{9}$ Differences in the time of the year that wages are set could also lead to serial correlation in the error term. 
wages $^{10}$. We adopted a first-order dynamic equation (in response to the firstorder serial correlation that was apparent when examining the data) ${ }^{11}$. Whilst this dynamic structure is not indicated explicitly by the theory underlying Svejnar's model (Svejnar's model is quite clearly a static model) the expression appears to be a natural extension of his model.

The short-run dynamic relationship can be expressed as ${ }^{12}$ :

$\Delta \mathrm{W}=\alpha_{1} \mathrm{~W}_{\mathrm{t}-1}+\alpha_{2} \Delta \mathrm{W}^{\mathrm{a}}+\alpha_{3} \mathrm{~W}_{\mathrm{t}-1}^{\mathrm{a}}+\alpha_{4} \Delta \mathrm{W}^{\mathrm{a}}+\alpha_{5} \mathrm{~W}_{\mathrm{t}-1}^{\mathrm{a}} \alpha_{6} \Delta \mathrm{R}+\alpha_{7} R_{\mathrm{t}-1}$

Where $W$ is the average earnings of coal industry employees.

$W^{a}$ is the average outside wage, proxied by average full-time male earnings in the State of New South Wales.

$A$ is the proportion of employees working in open-cut mines to all employees in the coal industry.

$R$ is net revenue in the coal industry.

$\Delta$ indicates current period change in the variable, hence $\Delta \mathrm{W}=\mathrm{W}_{\mathrm{t}}-\mathrm{W}_{\mathrm{t}-1}$.

In the long run, movements from the equilibrium position can be expected to approach zero and the lagged variables can be expected to approximate the current period variables. Thus, $\Delta W=0, \Delta W^{a}=0, \Delta A W^{a}=0$ and $\Delta R=0$ in the long run, and $W_{t}=\bar{W}$, $W_{t}^{a}=\bar{W}^{a}, A W^{a}{ }_{t}=A \bar{W}_{t}^{a}$ and $R_{t}=\bar{R}_{t}$. Solving for the long run wage effect provides:

$\overline{\mathrm{W}}_{\mathrm{t}}=-\alpha_{3} / \alpha_{1} \overline{\mathrm{W}}^{\mathrm{a}}-\alpha_{5} / \alpha_{1} \mathrm{~A} \overline{\mathrm{W}}^{\mathrm{a}}-\alpha_{7} / \alpha_{1} \overline{\mathrm{R}}$

\footnotetext{
${ }^{10}$ Some unsuccessful attempts are discussed in Lockwood and Manning, 1989. Possible avenues of future work in this area are discussed in Kennan and Wilson, 1989.

${ }^{11}$ Discussion of dynamic modelling is provided in Wickens and Breusch, 1988.

${ }^{12}$ This expression may be recognized as an unrestricted error corrective model.
} 
Results for the dynamic model are recorded in column one of Table 2. Introducing a dynamic adjustment model removes the serial correlation and heteroscedasticity that was apparent in the static model, the dynamic model also passes the functional form test which the static model failed. In fact, this model was exposed to a battery of diagnostic tests without revealing any significant misspecification ${ }^{13}$. The first-order dynamic specification is preferred to the static model. The coefficients can be interpreted to generate some interesting implications for both the dynamics of wage adjustment and the long-run equilibrium.

The negative coefficient on the lagged industry wage term $\left(w_{t-1}\right)$ implies that a wage gain in the previous period will be associated with a smaller wage gain in the next period. Hence, if the industry wage rose by $\$ 1$ in the previous period, then the industry wage would only rise by some 234 in the current period. The negative coefficient on the lagged industry wage was a standard result in the models tested, this result ensures that there will be a stable long-run solution to the model.

The long-run implications of the results are recorded in the lower section of the first column in Table 2. The coefficients suggest that the reservation wage for underground employees is 1.18 times the average outside wage, with the reservation wage of open-cut employees being 3.57 times the average outside wage. The difference between the reservation wages of the two sectors reflects the difference in skills and working conditions between underground and open cut mining. If there are no differences in the required skill levels and/or working

\footnotetext{
${ }^{13}$ These tests include $\mathrm{ARCH}$, and serial correlation, tests to three lags.
} 
conditions between the sectors then $\alpha_{1}=\alpha_{j}$ and $(1-\gamma)\left(\alpha_{1}-\alpha_{j}\right) A W^{a}=0$ in equation $(5)^{14}$. The difference was found to be 2.39 so that, prior to obtaining a share of net revenue, open cut employees receive a reservation wage which is more than double that of an underground employee. This estimate for the reservation wage in the open cut sector appears to be somewhat high, suggesting a need for further investigation. The employees share of net revenue is strongly significant at $14 \mathrm{c}$ in every dollar, supporting the application of Svejnar's model.

The data used in the static and dynamic estimations are the same, the difference in the results is due to the different specifications employed. For the results from the long-run model to be considered as valid, the variables in the long run version of the model should be cointegrated ${ }^{15}$. Whilst our tests were not exclusively supportive, it appears that the expression is cointegrated ${ }^{16}$.

\footnotetext{
${ }^{14} \mathrm{Hence}$, the estimating equation given an homogenous labor force is nested in equation ( 5 ).

${ }^{15}$ The long-run relationship between the variables in equation (5) can be regarded as the stationary steady-state relationship between a set of non-stationary variables. For this to be the case, the variables, which were found to be nonstationary (using the Dickey-Fuller and augmented Dickey-Fuller tests; Fuller, 1976) must be cointegrated. Cointegration of the non-stationary variables was supported by the CRDW test at the $90 \%$ level (Engle and Granger, 1987), although it was rejected by the Dickey-Fuller and augmented Dickey-Fuller tests. Furthermore, it is necessary to show that the particular linear combination of the variables shown as the long-run relationship should appear uniquely.
}

${ }^{16}$ Application of the technique proposed by Johansen and Juselius (1990) shows that there are two cointegrating relationships between the four variables in equation (5). It can be shown, however, that the cointegrating vector given as the long-run relationship in equation (5) appears uniquely in that equation: a restriction accepted at the $77 \%$ significance level. It seems valid, therefore, to treat the wage equation (5) separately from equations for the other three variables in the long-run solution. 
Annual compared to hourly earnings

The average industry wage $\left(W_{t}\right)$ used so far represents the average hourly earnings of an employee in the coal industry, most authors have used annual income rather than hourly $y^{17}$. Results for equation (5) using annual data are recorded in column three of Table 2. This expression passes rigorous diagnostic tests and appears to provide a better fit than that obtained using hourly data ${ }^{18}$. The size, and significance, of the coefficients change substantially. The reservation wage of underground employees falls from 1.19 to 0.81 times the average outside wage, and the open-cut reservation wage falls from 3.57 times the average outside wage to become 1.40 and insignificant. The share of net revenue accruing to employees using hourly data was some $14 \mathrm{c}$ in the dollar, with annual data this share increases to $19.5 \mathrm{c}$ in the dollar. This result is in accordance with the predicted upward bias in the share of net revenue when using annual data.

\section{Heterogenous and homogenous labor.}

Difficulties may arise if the unobservable reservation wage and the observable average outside wage display different growth paths over time, this indeed may be the case. The coal industry has displayed a systematic expansion of open cut

${ }^{17} \mathrm{~A}$ difficulty arises using annual data if the data does not allow for differences that may occur between years in the number of hours actually worked. It may be that in years of unusually high world demand for coal the industry responds by increasing the overtime of workers. This would result in a noticeable increase in the annual wage, coinciding with higher profits, which the simple model used here would misinterpret as an increase in the bargaining strength of the trade union. Similarly, if employees in the coal industry work substantially less hours. than do average male full time employees in the State, ignoring the hours worked would lead to a lower estimation of the reservation wage in the coal industry. Coal industry employees do in fact work less hours than average (having both a shorter working week, and longer periods of annual leave).

${ }^{18}$ The adjusted $R^{2}$ is higher and the ratio of the standard error of the regression to the mean of the dependent variable (SER/MDV) is lower. 
mining technology throughout the sample period, possibly changing the relative skill requirements within the industry as well as the comparative skill levels of industry employees with those of the average male employee in the State ${ }^{19}$. To consider this change in technology the coal industry has been considered in two parts: the sector using open cut mining technology, and the sector operating with underground mining technology. Thus, the possible heterogeneity of the labor force has been explicitly considered. As a comparative exercise a homogenous labor force was considered by estimating equation (3).

Results for the test of equation (3) are recorded in column four of Table 2 . Comparing these results to those provided when allowing for heterogenous labor (column one of Table 2) reveals that generalizing the model to allow for different reservation wages substantially improves the fit of the model (the adjusted $R_{2}$ increases from 0.27 to 0.64 ). All of the coefficients become highly significant, including the surplus term. Furthermore, the model passes rigorous diagnostic testing and the long run solution is well determined. In short, the generalized model exhibits none of the signs of mis-specification shown when considering labor as a homogenous group.

\section{Difference in bargaining shares}

Although the reservation wages have been allowed to differ across the sectors, the bargaining shares have been assumed to be homogenous across the sectors of the coal industry $\left(\tau_{i}=\tau_{j}=\tau\right)$. Similarly, the net revenue in both sectors has been

\footnotetext{
${ }^{19}$ With the advances in open cut mining in the New South Wales coal industry in the $1960 \mathrm{~s}$, the industry wage could be expected to rise to reflect the increased skill of new workers. This would result in a greater disparity between the industry wage and the alternative wage which the simple model would interpret as increased bargaining strength by the trade union.
} 
assumed to be equivalent to the industry net revenue $\left(R_{1}-R_{j}-R\right)$. These restrictions may be influential in the high estimate of the open cut reservation wage. The model was further generalized by introducing the term $\left(\tau_{1}-\tau_{j}\right)\left(q_{1} R(L) / L\right)$ to equation (5) and thereby allowing the surplus in the two sectors of the industry to differ.

The results are recorded in column 1 of Table 3, this generalization leads to six of the variables in the dynamic estimating equation being insignificant. This may be due to the possible presence of multicollinearity since the new variables added to this expression include non-linear combinations of other variables already being used ${ }^{20}$.

The size of the coefficients suggest that, whilst employees in the open-cut sector of the NSW coal industry receive a higher reservation wage than do underground employees, open-cut employees gain a much larger share of their sector's surplus than do underground employees. Implying that the higher earnings of open-cut employees are largely due to their bargaining share, rather than a high reservation wage, compared with estimates for the industry as a whole. The size of the standard errors on these coefficients, however, indicate that these estimates cannot be accepted using conventional testing criteria ${ }^{21}$.

${ }^{20}$ The zero order correlation measures between $O R$ and the other variables in the regression are all above 0.9 , with the exception of $\mathrm{W}^{\mathrm{a}}$ where the measure is 0.84 . There is also some indication of heteroscedasticity with the second and third lags of the error term.

${ }^{21}$ The size of these standard errors is apparently due to multicollinearity, applying this procedure to richer data with separate observations for each sector would avoid this difficulty. 


\section{Relationship with unemployment}

The unemployment rate in the state of NSW, $U$, the level of the unemployment benefit, B, and the level of employment in the coal industry, E, were each added individually to the estimation of equation (5). Results for these variable addition tests are recorded in columns 2,3 and 4 of Table 3 respectively. Each of these measures is not found to have a significant explanatory role in the regression 22 .

\section{Endogeneity and the profit term}

If $\omega \neq W^{\mathrm{a}}$, it may be argued that the surplus term would be mis-measured as crude surplus, $\mathrm{S}^{\mathrm{wa}}=\mathrm{R}(\mathrm{L})-\mathrm{W}^{\mathrm{a}} / \mathrm{L}$, and will be accordingly biased. We avoided this difficulty by incorporating the coefficient on $W^{a}$ into the surplus term, and rearranging the expression to be in terms of revenue net of production costs (excluding labor costs) per unit of labor, $R=R(L) / L$. Introducing net revenue in place of crude surplus adjusts the coefficient on the outside average wage by (1$\tau)$, otherwise the expressions are numerically equivalent ${ }^{23}$.

We also want to consider the possible bias involved in using a measure of firm profitability, $S^{w}=[R(L)-w L] / L$, rather than net revenue, $R$. The coefficient on net revenue, the share parameter $\tau$, was found to be 0.1414 . We know that there is a relationship between $r$ and $\rho$ (where $\rho$ is the estimating parameter if firm

${ }^{22} \mathrm{Although}$ there is evidence of multicollinearity across the unemployment rate $(U)$ and the weighted average outside wage $\left(A W^{a}\right)$. Whilst neither $U$ nor $A W^{a}$ is individually significant at conventional levels, a joint deletion test reveals that they have a combined significant explanatory role in the short run regression; $F(4,25)=8.6784$.

${ }^{23}$ This can be seen by comparing the results using $R$, in column 1 of Table 1 , with those using $\mathrm{S}^{\mathrm{wa}}$, in column 2 of Table 4 . 
profitability is used) such that $\rho=\tau /(1-\tau)$. Thus, we would expect $\rho=0.1647$. The estimated value for the coefficient on $\mathrm{S}^{w}$ was, however, found to be substantially lower than this at 0.1477 (recorded in column 3 of Table 4). This result is consistent with the prediction that exogenous shocks to the wage influence the profit term and bias the estimating parameter downwards.

A further source of endogeneity and the surplus. term could stem from a causal relationship between wages and productivity such that increases in wages induce greater productivity. This premiss can be considered via a variable addition test by including the deviation from trend in output per labor unit, DTR, into the expression of equation (5). Results of this test are recorded in column 1 of Table 4 where it can be seen that the effect of DTR is clearly insignificant.

\section{Efficlency wages and bargaining}

We have argued that bargaining models predict that exogenous changes to the surplus term will be positively correlated with changes in the wage rate, whereas the efficiency wage model predicts that such exogenous demand shocks should have no systematic impact on the wage. By introducing instruments for demand conditions which are believed to be exogenous to the revenue term, and implementing a 2-stage-least-squares procedure, these competing predictions can be tested. Furthermore, the estimate of the share of surplus, $\tau_{b}$, found in this procedure can be argued to represent only a bargaining model effect. Whilst the estimate of $r=0.1414$, found using the unrestricted test of equation (5), represents both a bargaining and an efficiency wage effect. 
The instruments ${ }^{24}$ chosen to represent exogenous demand shocks are exports of coal from America ${ }^{25}$, XUSA, and the foreign exchange rate ${ }^{26}$, ER. Results for this test are provided in column four of Table 4 . The value of $\tau_{b}$ is found to be 0.1262 , the difference between $\tau$ and $\tau_{b}$ is therefore $0.0152 .^{27}$ This finding provides clear support for the bargaining models, whilst suggesting that the extent of efficiency wage effects is not strong in this industry ${ }^{28}$.

\section{Conclusion}

The reduced form of Svejnar's model is investigated in this paper. The major premise of his model, that there is a positive relationship between the industry surplus and the industry wage is strongly supported; for every extra dollar of net revenue in the industry the employees receive $14 \mathrm{c}$ above their reservation wage.

A first-order dynamic adjustment model is used to allow for a more complicated dynamic structure than that assumed in the theoretical model. The outcome is an estimating equation which passes stringent diagnostic requirements and shows no

${ }^{24}$ These instruments have not been chosen to instrument net revenue, rather they have been chosen to instrument exogenous changes to net revenue. Regressing the instruments against net revenue reveals that they only explain some 308 of total variation $\left(R^{2}=0.2992\right)$. It would seem that the variation that these instruments does pick up in net revenue is, however, that which is important in explaining the relationship between industry surplus and the wage rate.

${ }^{25}$ Total coal exported from the USA, including anthracite, measured in 1000 net tons, National Coal Association (1988; II-1).

${ }^{26}$ The market rate/central par rate over the period average of Australian currency per units of US dollars, International Monetary Fund (1985;12-17 and 1989;207).

${ }^{27} \tau-\tau_{\mathrm{b}}=0.1414-0.1262=0.0152$

${ }^{28}$ The standard error on this term is 0.0385 in the 2SLS estimation, it is 0.0277 in the OLS estimation of equation (5). 
significant signs of mis-specification. This equation is in strong contrast to the application of the static estimating equation proposed by Svejnar's. We then explore the direction and the extent of biases that occur in the estimation of the insider weighting when the variation in the hours of work, the composition of the labor force, and the endogeniety of measured profits are not controlled for.

Furthermore, we argue that bargaining models predict that exogenous demand shocks to profitability should be passed on to wages, whereas the 'pure' efficiency wage models of effort or shirking predict no such effect. Application of this directly testable prediction suggests that the majority of the estimated insider weighting is explained by the bargaining models rather than the efficiency wage models.

\section{Bibliography}

Andrews, Martyn and Alan Harrison. 1988. 'Testing for Efficient Contracts in Unionized Labor markets', Discussion Paper E5201, Department of Econometrics and Social Statistics, University of Manchester.

Binmore, Ken, Rubinstein, Ariel, and Asher Wolinsky. 1986. 'The Nash Bargaining Solution in Economic Modelling', Rand Journal 17(2), 176-188.

Blanchflower, David G., Oswald, Andrew J. and Mario D. Garrett. 1990. 'Insider Power in Wage Determination', Economica 57, May, 143-170.

Dowrick, Steve. 1990. 'The Relative Profitability of Nash Bargaining on the Labor Demand Curve or the Contract Curve', Economics Letters, forthcoming.

Engle, Robert F. and Granger, C. W. J. 1987. 'Co-Integration and Error Correction: Representation, Estimation, and Testing'. Econometrica 55(2), 251-276.

Fuller, Wayne. 1976. Introduction to Statistical Time Series. John Wiley, New York.

Holly, Sean. and Smith, Peter. 1987. 'A Two-Sector Analysis of the U.K. Labor Market'. Oxford Bulletin of Economics and Statistics 49(1), 79-102.

Johansen, Soren and Katrina Juselius. 1990. 'Maximum Likelihood Estimation and Inference on Cointegration - With Application to the Demand for Money'. Oxford Bulletin of Economics and Statistics. 52(2), 169-210.

Karier, Thomas. 1985. 'Unions and Monopoly Profits'. Review of Economics and Statistics 67(1), 34-42.

Kennan, John and Robert Wilson. 1989. 'Strategic Bargaining Models and Interpretation of Strike Data'. Journal of Applied Econometrics 4, S87S130. 
Krueger, Alan B. and Lawrence H. Summers. 1988. 'Efficiency Wages and the Inter-Industry Wage Structure'. Econometrica 56(2), 259-293.

Lockwood, Ben and Alan Manning. 1989. 'Dynamic Wage-Employment Bargaining with Employment Adjustment Costs'. Economic Journal 99, December, 1143-1158.

McDonald, I. M. and Solow, R. M. 1981. 'Wage Bargaining and Employment'. American Economic Review 71, 896-908.

Mishe1, Lawrence. 1986. 'The Structural Determinants of Union Bargaining Power', Industrial and Labor Relations Review 40(1), 90-104.

Nickell, S. J. and Andrews, M. 1983. 'Unions, Real Wages and Employment in Britain, 1951-79'. Oxford Economic Papers 35(S), 183-206.

Nicke11, Stephen and Sushil Wadhwani. 1990. 'Insider Forces and Wage Determination', Economic Journal 100, June, 496-509.

Oswald, Andrew J. 1985. 'The Economic Theory of Trade Unions: an Introductory Survey'. Scandinavian Journal of Economics 87(2), 160-193.

svejnar, Jan. 1986. 'Bargaining Power, Fear of Disagreement, and Wage Settlements: Theory and Evidence from U.S. Industry', Econometrica 54(5), $1055-1078$.

Wickens, M. R. and Breusch, T. S. 1988. 'Dynamic Specification, the Long-Run and the Estimation of Transformed Regression Models'. Economic Journal 98(S), $189-205$.

\section{Data Sources}

Australian Bureau of Statistics. Australian National Accounts: Estimates of Capital Stock, 1985-86. Canberra, Australia. Catalogue No. 5221.0.

-..-Average Weekly Earnings, States and Australia. Canberra, Australia. Catalogue No. 6302.0, various issues.

-..-Labor Statistics, Australia. 1975-1988. Canberra, Australia. Catalogue No. 6101.0 .

-..--Mining NSW. Canberra, Australia. Catalogue No. 8401.1. 1976-77 to 1988.

-..--NSW Annual Year Book. Canberra, Australia, various issues.

Joint Coal Board. Black Coal in Australia: A Statistical Year Book. 1985-86 and 1986-87. Sydney, Australia.

National Coal Association. Coal Data, 1988 Edition. Washington DC, USA.

International Monetary Fund. International Financial Statistics: Supplement on Exchange Rates. Supplement Series No. 9, 1985. Washington DC, USA.

...-.-International Financial Statistics: Yearbook 1989. Washington DC, USA.

Commonwealth Bureau of Census and Statistics. Labor Report. No. 41(1952)-No 58 (1973). Canberra, Australia.

-...-New South Wales. Mining Industries. Detailed Statistics of Operations and Minerals Produced. Canberra, Australia. 1968-69 to 1970-71.

...--Statistical Bulletin: Mining and Quarrying. Nos 1-17, 1952-68. Canberra, Australia.

Reserve Bank of Australia. Bulletin. July, 1987 and 1988 . $1949-50$ to 1984-85:

Tables. W. E. Norton, and P. J. Kennedy. November, 1985. 
Table 1

\begin{tabular}{|c|c|c|c|c|c|c|}
\hline Definition & Var & $\operatorname{Max}$ & Min & Mean & Sd-dev $C$ & oef-var \\
\hline Ave coal industry earngs: hourly & $\mathrm{W}$ & 3.7314 & 0.9939 & 2.0739 & 0.9338 & 0.4503 \\
\hline Ave outside earngs:hourly & $\mathbf{W}^{\mathbf{a}}$ & 1.8499 & 0.7202 & 1.2559 & 0.3991 & 0.3178 \\
\hline Weighted $W^{\mathrm{a}}:$ hourly & $A W^{\mathbf{a}}$ & 0.3963 & 0.0074 & 0.0918 & 0.1181 & 1.2862 \\
\hline Net revenue/L: hourly & $\mathbf{R}$ & 7.4951 & 1.7819 & 3.6388 & 1.7555 & 0.4824 \\
\hline Ave coal industry earngs:annual & $W^{\prime}$ & 5929.7 & 1764.4 & 3569.7 & 1386.6 & 0.3884 \\
\hline Ave outside earngs: annual & $W^{a^{\prime}}$ & 3876.9 & 1533.0 & 2737.2 & 781.29 & 0.2854 \\
\hline Weighted $W^{\mathrm{a}}:$ annual & $\mathrm{AW}^{\mathbf{a}}$ & 828.50 & 17.448 & 194.85 & 246.20 & 1.2636 \\
\hline Net revenue/L:annual & $\mathbf{R}^{\prime}$ & 12224.6 & 3197.4 & 6257.8 & 2733.8 & 0.4356 \\
\hline Exchange rate (AUS:USA) & ER & 1.4905 & 0.6974 & 0.9365 & 0.1749 & 0.1868 \\
\hline Coal exports from USA & $\mathrm{x}$ & 112.50 & 33.900 & 61.442 & 19.881 & 0.3236 \\
\hline Unemployment rate in NSW & $\mathrm{U}$ & 15.390 & 0.1200 & 3.9467 & 4.5137 & 1.1437 \\
\hline Unemployment Benefit in NSW & B & 30.430 & 5.0000 & 17.592 & 8.3001 & 0.4718 \\
\hline Employment in coal industry & $\mathbf{E}$ & 20911.0 & 11414.0 & 15804.9 & 3094.6 & 0.1958 \\
\hline Ave total output coal/L:hourly & $\mathrm{T}$ & 0.0028 & 0.0004 & 0.0013 & 0.0006 & 0.5013 \\
\hline
\end{tabular}


Table 2 .

\begin{tabular}{|c|c|c|c|c|}
\hline Expression & hourly & static & annual & no skill adf \\
\hline regressand & $\Delta \mathrm{W}_{\mathrm{t}}$ & $w_{t}$ & $\Delta W^{\prime}{ }_{t}$ & $\Delta \mathrm{W}_{\mathrm{t}}$ \\
\hline \multirow[t]{8}{*}{$\frac{\text { coefficients }}{\text { ( } t \text { values) }}$} & $\begin{array}{c}0.0534 \\
(0.7650)\end{array}$ & $\begin{array}{l}-0.1365 \\
(-1.7264) \#\end{array}$ & $\begin{array}{l}159.9104 \\
(1.5231)\end{array}$ & $\begin{array}{c}-0.1443 \\
(-1.6640)\end{array}$ \\
\hline & $\begin{array}{l}-0.7710 W_{t-1} \\
(-4.2841) *\end{array}$ & $\begin{array}{l}1.2673 \mathrm{~W}^{\mathrm{a}} \\
(11.8635) *\end{array}$ & $\begin{array}{r}-0.3718 W^{\prime}{ }^{t-1} \\
(-2.6879)^{*}\end{array}$ & $\begin{array}{r}-0.1912 W_{t-1} \\
(-2.3137) *\end{array}$ \\
\hline & $\begin{array}{c}0.5053 \Delta \mathrm{W}^{\mathrm{a}} \\
(2.1320) *\end{array}$ & $\begin{array}{c}2.5703 A W^{a} \\
(10.6066) *\end{array}$ & $\begin{array}{l}0.1296 \Delta W^{a} \\
(0.7311)\end{array}$ & $\begin{array}{l}0.6231 \Delta W^{a} \\
(2.0636) \star\end{array}$ \\
\hline & $\begin{array}{l}0.7809 W^{a}{ }_{t-1} \\
(3.6962) *\end{array}$ & $\begin{array}{l}0.1052 R \\
(4.7068) *\end{array}$ & $\begin{array}{l}0.2412 \mathrm{~W}^{\mathrm{al}} \mathrm{t}-1 \\
(1.7759) \#\end{array}$ & $\begin{array}{c}0.4164 \mathrm{~W}^{\mathrm{a}} \mathrm{t-1} \\
\quad(2.0353) \#\end{array}$ \\
\hline & $\begin{array}{l}7.2050 \Delta \mathrm{AW}^{\mathrm{a}} \\
(5.6966) \star\end{array}$ & & $\begin{array}{l}4.2941 \Delta A W^{a} \\
(5.2457) *\end{array}$ & \\
\hline & $\begin{array}{l}1.5811 \mathrm{AW}_{\mathrm{t}-1}^{\mathrm{a}} \\
(2.8265) *\end{array}$ & & $\begin{array}{l}0.1831 \mathrm{AW}^{\mathrm{a} \prime}{ }_{\mathrm{t}-1} \\
(0.6696)\end{array}$ & \\
\hline & $\begin{array}{r}0.1006 \Delta R \\
(4.0995) *\end{array}$ & & $\begin{array}{l}0.1455 \Delta \mathrm{R}^{\prime} \\
(7.4559) *\end{array}$ & $\begin{array}{r}0.0570 \Delta \mathrm{R} \\
(1.7262) \#\end{array}$ \\
\hline & $\begin{array}{l}0.1090 \mathrm{R}_{\mathrm{t}-1} \\
(3.4237) *\end{array}$ & & $\begin{array}{l}0.0726 R^{\prime}{ }_{t-1} \\
(2.8891) *\end{array}$ & $\begin{array}{c}0.0178 R_{t-1} \\
(0.5831)\end{array}$ \\
\hline \multicolumn{5}{|l|}{ diagnostics } \\
\hline $\begin{array}{l}\text { adj } R^{2} \\
\text { SER/MDV } \\
\text { F-stat } \\
\text { serial } \operatorname{corr}(L M) \\
\text { heterosced(LM) } \\
\text { funct form(LM) } \\
\text { normality(LM) } \\
\text { no of observ }\end{array}$ & $\begin{array}{l}0.6427 \\
0.9785 \\
9.7376 \star \\
0.1810 \\
0.8358 \\
0.2973 \\
0.2634 \\
35\end{array}$ & $\begin{array}{l}0.9865 \\
0.0523 \\
854.0126 * \\
7.9457 * \\
7.0789 * \\
0.2085 \\
1.6119 \\
36\end{array}$ & $\begin{array}{l}0.7556 \\
0.9001 \\
16.0129 * \\
2.2689 \\
0.0239 \\
0.0093 \\
2.3613 \\
35\end{array}$ & $\begin{array}{l}0.2667 \\
1.4011 \\
3.4736 * \\
0.1001 \\
4.7653 * \\
0.3923 \\
1.5399 \\
35\end{array}$ \\
\hline \multirow[t]{4}{*}{$\begin{array}{l}\text { Long run model } \\
(t \text { values })\end{array}$} & $\begin{array}{c}0.0693 \\
(0.7640)\end{array}$ & & $\begin{array}{l}430.0979 \\
(1.3340)\end{array}$ & $\begin{array}{c}-0.7547 \\
(-2.0749) *\end{array}$ \\
\hline & $\begin{array}{c}1.0128 \overline{\mathrm{W}}^{\mathrm{a}} \\
(7.0791) *\end{array}$ & & $\begin{array}{c}0.6487 \overline{\mathrm{W}}^{\mathrm{a}} \mathrm{r} \\
(3.2508) *\end{array}$ & $\begin{array}{l}2.1778 \bar{W}^{\mathbf{a}} \\
(3.3091) *\end{array}$ \\
\hline & $\begin{array}{l}2.0507 \overline{\mathrm{AW}}^{\mathrm{a}} \\
(6.4096) *\end{array}$ & & $\begin{array}{l}0.4797 \overline{\mathrm{AW}}^{\mathrm{a}} \text { ' } \\
(0.8496)\end{array}$ & \\
\hline & $\begin{array}{c}0.1414 \overline{\mathrm{R}} \\
(5.0967) *\end{array}$ & & $\begin{array}{c}0.1953 \overline{\mathrm{R}}^{\prime} \\
(3.9561) *\end{array}$ & $\begin{array}{c}0.0931 \bar{R} \\
(0.5934)\end{array}$ \\
\hline
\end{tabular}

* Significant at 958 \# Significant at 908

SER/MDV:standard error of regression/mean of dependent variable. 
Table 3.

\begin{tabular}{|c|c|c|c|c|}
\hline regressand & $\Delta \mathrm{W}_{\mathrm{t}}$ & $\Delta \mathrm{W}_{\mathrm{t}}$ & $\Delta \mathrm{W}_{\mathrm{t}}$ & $\Delta \mathrm{W}_{\mathrm{t}}$ \\
\hline \multirow[t]{10}{*}{$\frac{\text { coefficients }}{\text { (t values) }}$} & $\begin{array}{c}0.0921 \\
(0.9221)\end{array}$ & $\begin{array}{c}0.0309 \\
(0.4165)\end{array}$ & $\begin{array}{c}0.0606 \\
(0.7543)\end{array}$ & $\begin{array}{l}-0.0067 \\
(-0.0457)\end{array}$ \\
\hline & $\begin{array}{l}-0.6837 \mathrm{~W}_{\mathrm{t}-1} \\
(-3.3062) \star\end{array}$ & $\begin{array}{r}-0.7000 W_{t-1} \\
(-3.5755) *\end{array}$ & $\begin{array}{r}-0.7949 W_{t-1} \\
(-4.1294) *\end{array}$ & $\begin{array}{r}-0.7244 W_{t-1} \\
(-3.8319) \star\end{array}$ \\
\hline & $\begin{array}{l}0.3655 \Delta \mathrm{W}^{\mathrm{a}} \\
(1.3254)\end{array}$ & $\begin{array}{l}0.2947 \Delta W^{\mathrm{a}} \\
(0.9081)\end{array}$ & $\begin{array}{l}0.5386 \Delta W^{a} \\
(1.9849) \#\end{array}$ & $\begin{array}{l}0.4752 \Delta W^{\mathrm{a}} \\
(1.8987) \#\end{array}$ \\
\hline & $\begin{array}{l}0.7665 \mathrm{~W}^{\mathrm{a}} \mathrm{t-1} \\
(3.4884) \star^{-1}\end{array}$ & $\begin{array}{l}0.7620 \mathrm{~W}^{\mathrm{a}}{ }_{\mathrm{t}-1} \\
(3.0503)^{\star}\end{array}$ & $\begin{array}{r}0.7822 \mathrm{~W}^{\mathrm{a}}{ }^{\mathrm{t}-1} \\
(3.1722) *\end{array}$ & $\begin{array}{l}0.7371 \mathrm{~W}^{\mathrm{a}}{ }_{\mathrm{t}-1} \\
\quad(3.1513) *\end{array}$ \\
\hline & $\begin{array}{l}7.0301 \Delta \mathrm{AW}^{\mathrm{a}} \\
(5.1059) *\end{array}$ & $\begin{array}{l}7.6304 \Delta A W^{\mathrm{a}} \\
(4.2761) *\end{array}$ & $\begin{array}{l}7.2383 \Delta A W^{a} \\
(5.5263) *\end{array}$ & $\begin{array}{r}6.9247 \Delta A W^{\mathrm{a}} \\
(5.0884) *\end{array}$ \\
\hline & $\begin{array}{l}0.7243 A W^{a}{ }_{t-1} \\
(0.8235)\end{array}$ & $\begin{array}{c}0.9939 \mathrm{AW}^{\mathrm{a}}{ }^{\mathrm{t}-1} \\
(1.3382)^{-1}\end{array}$ & $\begin{array}{c}1.6152 \mathrm{AW}^{\mathrm{a}}{ }^{\mathrm{t}-1} \\
(2.7217)^{*}\end{array}$ & $\begin{array}{r}1.3797 \mathrm{AW}^{\mathrm{a}} \mathrm{t-1} \\
\quad(2.2640) *\end{array}$ \\
\hline & $\begin{array}{l}-0.0466 \Delta R \\
(-0.2303)\end{array}$ & $\begin{array}{l}0.1148 \Delta \mathrm{R} \\
(4.0711) *\end{array}$ & $\begin{array}{l}0.0976 \Delta R \\
(3.5509) *\end{array}$ & $\begin{array}{l}0.0988 \Delta R \\
(3.9066) *\end{array}$ \\
\hline & $\begin{array}{l}0.1623 R_{t-1} \\
(1.0492)\end{array}$ & $\begin{array}{r}0.0897 R_{t-1} \\
(2.3314)^{*}\end{array}$ & $\begin{array}{l}0.1027 \mathrm{R}_{\mathrm{t}-1} \\
\quad(2.5211) \star\end{array}$ & $\begin{array}{l}0.0997 R_{t-1} \\
\quad(2.9500) *\end{array}$ \\
\hline & $\begin{array}{l}0.1033 \Delta \mathrm{QR} \\
(1.8847) \#\end{array}$ & $\begin{array}{r}-0.0162 \Delta U \\
(-0.9250)\end{array}$ & $\begin{array}{l}-0.0018 \Delta B \\
(-0.1760)\end{array}$ & $\begin{array}{l}0.0147 \Delta \mathrm{E} \\
(0.7965)\end{array}$ \\
\hline & $\begin{array}{l}0.0454 Q_{R_{t-1}} \\
(0.7769) *\end{array}$ & $\begin{array}{c}0.0059 U_{t-1} \\
(0.3265)\end{array}$ & $\begin{array}{c}0.0034 B_{t-1} \\
(0.3044)\end{array}$ & $\begin{array}{r}0.0047 \mathrm{E}_{\mathrm{t}-1} \\
(0.7703)\end{array}$ \\
\hline $\begin{array}{l}\text { diagnostics } \\
\text { adj } R^{2} \\
\text { SER } \\
\text { F-stat } \\
\text { serial corr(LM) } \\
\text { heterosced(LM) } \\
\text { funct form(LM) } \\
\text { normality(LM) } \\
\text { no of observ }\end{array}$ & $\begin{array}{l}0.6399 \\
0.0729 \\
7.7121 \star \\
0.9745 \\
0.7395 \\
0.0018 \\
1.0243 \\
35\end{array}$ & $\begin{array}{l}0.6439 \\
0.0725 \\
7.8307 * \\
0.0205 \\
0.5203 \\
2.1223 \\
1.0996 \\
35\end{array}$ & $\begin{array}{l}0.6182 \\
0.0751 \\
7.1157 * \\
0.1115 \\
0.5010 \\
0.1726 \\
0.4697 \\
35\end{array}$ & $\begin{array}{l}0.6301 \\
0.0739 \\
7.4353 * \\
1.1477 \\
0.3947 \\
0.1508 \\
0.7544 \\
35\end{array}$ \\
\hline \multirow[t]{5}{*}{$\begin{array}{l}\text { Long run model } \\
(t \text { values })\end{array}$} & $\begin{array}{c}0.1347 \\
(0.9379)\end{array}$ & $\begin{array}{c}0.0441 \\
(0.4155)\end{array}$ & $\begin{array}{c}0.0762 \\
(0.7525)\end{array}$ & $\begin{array}{c}-0.0092 \\
(-0.0457)\end{array}$ \\
\hline & $\begin{array}{r}1.1211 \bar{W}^{\mathrm{a}} \\
(5.8059) \star\end{array}$ & $\begin{array}{l}1.0886 \overline{\mathrm{W}}^{\mathrm{a}} \\
(5.6005) *\end{array}$ & $\begin{array}{l}0.9840 \bar{W}^{\mathrm{a}} \\
(5.0051) *\end{array}$ & $\begin{array}{l}1.0175 \bar{W}^{\mathrm{a}} \\
(5.6187) *\end{array}$ \\
\hline & $\begin{array}{l}1.0594 \overline{\mathrm{AW}}^{\mathrm{a}} \\
(0.9630)\end{array}$ & $\begin{array}{l}1.4199 \overline{\mathrm{AW}}^{\mathrm{a}} \\
(1.6776)\end{array}$ & $\begin{array}{l}2.0320 \overline{\mathrm{AW}}^{\mathrm{a}} \\
(5.9537) *\end{array}$ & $\begin{array}{l}1.9046 \overline{\mathrm{AW}}^{\mathrm{a}} \\
(4.3719) *\end{array}$ \\
\hline & $\begin{array}{l}0.0664 \bar{R} \\
(0.8679)\end{array}$ & $\begin{array}{c}0.1281 \bar{R} \\
(2.6805) *\end{array}$ & $\begin{array}{c}0.1292 \bar{R} \\
(3.0153) *\end{array}$ & $\begin{array}{c}0.1376 \bar{R} \\
(4.4112) *\end{array}$ \\
\hline & $\begin{array}{l}0.2374 \overline{\mathrm{QR}} \\
(0.9946)\end{array}$ & $\begin{array}{l}0.0084 \bar{U} \\
(0.3326)\end{array}$ & $\begin{array}{l}0.0043 \overline{\mathrm{B}} \\
(0.3053)\end{array}$ & $\begin{array}{l}0.0065 \bar{E} \\
(0.7371)\end{array}$ \\
\hline
\end{tabular}

* Significant at 958 \# Significant at 908 
Table 4.

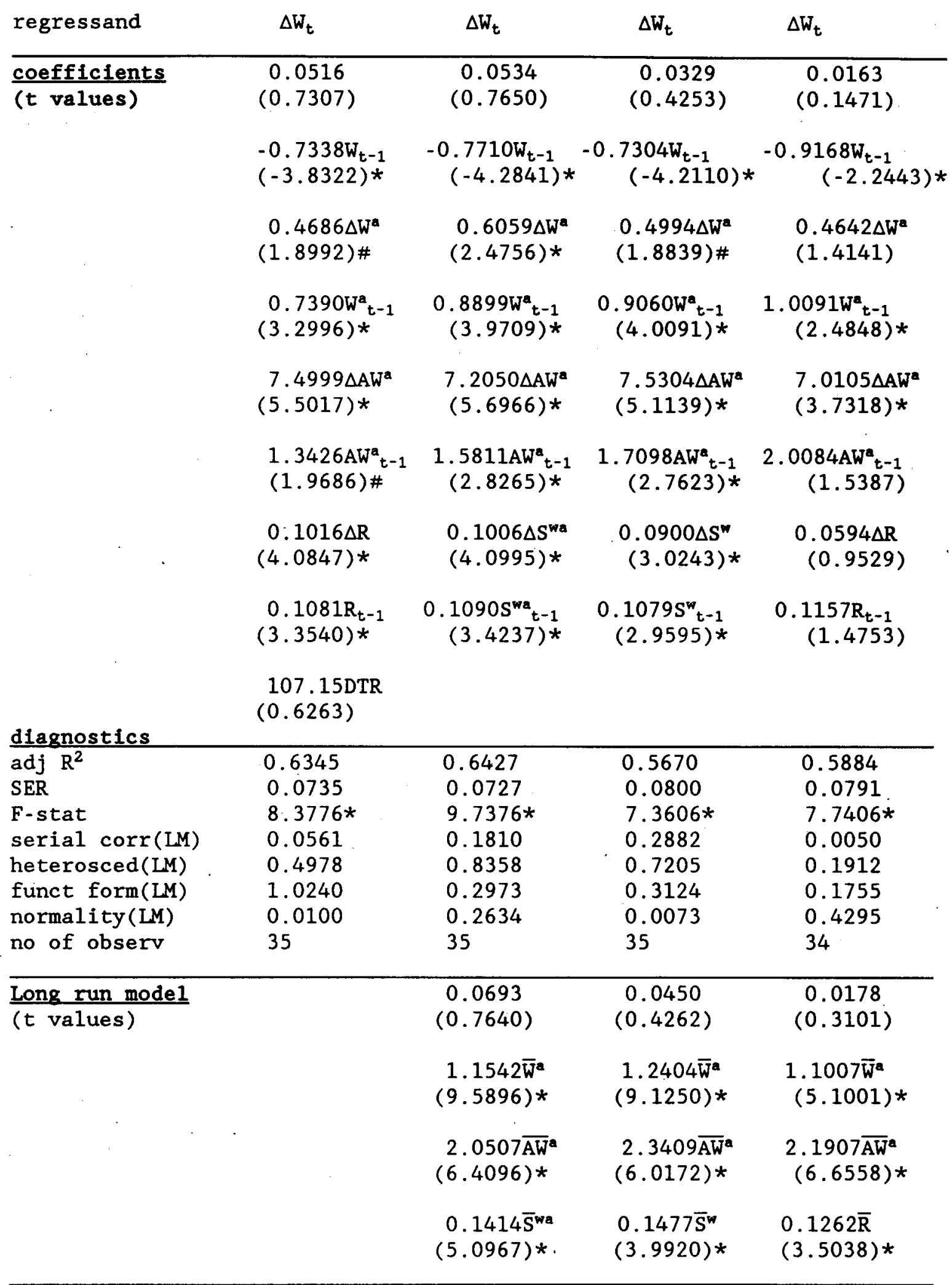

* Significant at 958 \# Significant at 908 